MÁrLon de Freitas FonSECA ${ }^{1}$

ClaUdio Moura AndRADE JUNIOR ${ }^{2}$

Eduardo de Almeida Nogueira ${ }^{3}$

Felipe Ventura Sessa ${ }^{4}$

Claudio Peixoto Crispi 2

Original Article

Keywords

Hysteroscopy/adverse effects Minimally invasive surgical procedures Safety management Uterine myomectomy

Palavras-chave

Histeroscopia/efeitos adversos Procedimentos cirúrgicos minimamente invasivos

Conduta de segurança Miomectomia uterina

\section{Predictors of fluid intravasation during operative hysteroscopy: a preplanned prospective observational study with 200 cases}

\author{
Preditores de intravasamento durante histeroscopia cirúrgica: \\ um estudo observacional prospectivo com 200 casos
}

Abstract

PURPOSE: To verify the predictors of intravasation rate during hysteroscopy. METHODS: Prospective observational study (Canadian Task Force classification II-1). All cases ( $\mathrm{n}=200$ women; 22 to 86 years old) were treated in an operating room setting. Considering respective bag overfill to calculate water balance, we tested two multiple linear regression models: one for total intravasation $(\mathrm{mL})$ and the other for absorption rate $\left(\mathrm{mL}^{\mathrm{m}} \mathrm{min}^{-1}\right)$. The predictors tested (independent variables) were energy (mono/bipolar), tube patency (with/without tubal ligation), hysterometry (cm), age $\leq 50$ years, body surface area $\left(\mathrm{m}^{2}\right)$, surgical complexity (with/without myomectomy) and duration (min). RESULTS: Mean intravasation was significantly higher when myomectomy was performed $(442 \pm 616$ versus $223 \pm 332 \mathrm{~mL} ; \mathrm{p}<0.01)$. In the proposed multiple linear regression models for total intravasation (adjusted $R^{2}=0.44 ; p<0.01$ ), the only significant predictors were myomectomy and duration $(p<0.01)$.In the proposed model for intravasation rate $\left(R^{2}=0.39 ; p<0.01\right)$, only myomectomy and hysterometry were significant predictors ( $p=0.02$ and $p<0.01$, respectively). CONCLUSIONS: Not only myomectomy but also hysterometry were significant predictors of intravasation rate during operative hysteroscopy.

\section{Resumo}

OBJETIVO: Testar preditores do ritmo de intravasamento durante histeroscopia cirúrgica. MÉTODOS: Estudo prospectivo observacional (classificação: Canadian Task Force II-1) incluindo casos conduzidos em centro cirúrgico (n=200 mulheres; 22 a 86 anos de idade). Considerando os erros de aferição nas embalagens de solução de irrigação para calcular o balanço hídrico, nós testamos dois modelos de regressão linear múltipla: um para intravasamento total (mL) e outro para ritmo de intravasamento (mL. $\mathrm{min}^{-1}$ ). Os preditores testados (variáveis independentes) foram energia (mono/ bipolar), permeabilidade tubária (com/sem ligadura tubária), histerometria (cm), status ovariano (idade $\leq 50$ anos), área de superfície corporal $\left(\mathrm{m}^{2}\right)$, complexidade de cirurgia (com/sem miomectomia) e tempo de ressecção (min). RESULTADOS: $\bigcirc$ intravasamento médio foi significativamente maior quando miomectomia foi realizada $1442 \pm 616$ versus $223 \pm 332 \mathrm{~mL}, \mathrm{p}<0,01)$. No modelo proposto para intravasamento total $\left(R^{2}\right.$ ajustado=0,44; $\left.p<0,01\right)$, os únicos preditores significativos foram miomectomia e tempo de duração $(p<0,01)$. No modelo proposto para a taxa de intravasamento $\left(R^{2}=0,39 ; p<0,01\right)$, somente miomectomia e histerometria foram preditores significativos $(p=0,02$ e $p<0,01$, respectivamente). CONCLUSÕES: Não só a miomectomia mas também a histerometria são preditores significativo da taxa de intravasamento durante histeroscopia cirúrgica.
Correspondence

Málon de Freitas Fonseca Avenida Rui Barbosa, 716 - Flamengo Zip code: $22250-020$ Rio de Janeiro (RJ), Brazil

Received 09/01/2014

Accepted with modifications $10 / 30 / 2014$
Anesthsiology and Gynecology Services, Instituto Nacional de Saúde da Mulher, da Criança e do Adolescente Fernandes Figueira, Fundação Oswaldo Cruz - FIOCRUZ - Rio de Janeiro (RJ), Brazil.

'Anesthesiology Service, Instituto Nacional de Saúde da Mulher, da Criança e do Adolescente Fernandes Figueira, Fundação Oswaldo Cruz - FIOCRUZ- Rio de Janeiro (R)), Brazil.

${ }^{2}$ Centro de Vídeo-endoscopia São Paulo - CEVESP-Barra - Rio de Janeiro (RJ), Brazil.

${ }^{3}$ Anesthesiology Service, Hospital Central da Polícia Militar - HCPM-RJ - Rio de Janeiro (RJ), Brazil.

${ }^{4}$ Felow at CNPa, Instituto Nacional de Saúde da Mulher, da Criança e do Adolescente Fernandes Figueira, Fundação Oswaldo Cruz FIOCRUZ - Rio de Janeiro (RJ), Brazil.

Conflict of interests: none. 


\section{Introduction}

Besides transurethral resection of the prostate, operative hysteroscopy $(\mathrm{OH})$ is an endoscopic surgery in which undesirable absorption of irrigation fluids is a major risk factor for complications ${ }^{1-5}$. Distension media, if absorbed systemically in sufficient amounts, can trigger adverse events, including life-threatening complications. Consequently, the Practice Committee of the Advanced Minimally Invasive Gynecology Worldwide (AAGL) has recently stated that understanding the physical properties and the potential risks associated with the use of the various distending media is critical for the safe performance of hysteroscopic procedures ${ }^{6}$.

Operative hysteroscopy has been the treatment of choice in symptomatic patients with a submucous myoma with diameter of $6 \mathrm{~cm}$ or less ${ }^{7}$ whereas the excessive intravasation of the fluid used to distend and irrigate the uterine cavity has been the main complication during hysteroscopic myomectomy ${ }^{8,9}$. Complications such as cardiovascular collapse and non cardiogenic pulmonary edema may occur if large volumes of any distension media are rapidly absorbed ${ }^{10-14}$. Still, fluid overload becomes quite dangerous when a solution lacks electrolytes (i.e. sodium) because of the risk of cerebral edema and dilutional hyponatremia ${ }^{15-17}$, condition in which immediate intensive approach is necessary ${ }^{18}$.

In endoscopic resections, both monopolar (which needs non-electrolytic solutions as distension fluid) or bipolar (more expensive technique, which accepts electrolytic/ ionic solutions ${ }^{19,20}$ ) probes can be used for performing hysteroscopic adhesiolysis, resection of uterine septum, endometrium, polyps and fibroids ${ }^{10,13,21-24}$. In fact, both techniques have been widely used over the last decade ${ }^{14,25,26}$. Recently, we have hypothesized that endoscopic surgeries with bipolar energy are associated with higher absorption of irrigation fluid due to higher permissibility of pressure and surgical time when an electrolytic solution is used.

Although resection time is an obvious issue regarding total fluid absorption during endoscopic surgeries, other risk factors for fluid overload during $\mathrm{OH}$ (i.e. complex myomectomy or large/ample adhesiolysis) are not completely elucidated because no studies have tested (and quantified) their independent contribution or relation to fluid loss ${ }^{8}$. Yet, there is few published information concerning predictors of complications associated to $\mathrm{OH}^{10,14}$. The objective of this study was to assess (under a multivariate context) potential predictors of intravasation rate in order to improve the prompt identification of risky cases by both anesthetists and hysteroscopists.

\section{Methods}

In this preplanned prospective observational, we assessed 200 consecutive hysteroscopic surgeries performed from April 2007 to March 2008. The inclusion criterion was all women submitted to $\mathrm{OH}$ with resectoscope under identically controlled intrauterine distension pressure.

Patients were anesthetized in an operating room setting using general $(88 \%)$ or spinal $(12 \%)$ anesthesia according to clinical criteria and patients' preferences. The cervical canal was dilated to Hegar 10 or 11 before the rigid resectoscope pass into the uterine cavity. The same hysteroscopy equipment was used for every case: a slightly fore-oblique $30^{\circ}$ telescope with an outer diameter of $4 \mathrm{~mm}$ and an internal/external sheaths of $10 \mathrm{~mm}$ outer diameter that provide a constant inflow and outflow of distension fluid for generating a continuous and efficient flow system inside the uterine cavity.

With respect to intrauterine pressure, intra-operatory distension of the uterus was identically performed with Stryker ${ }^{\circledR}$ Endoscopy Pump (USA) with no suction system. The maximal fluid pressure (superior limit) was set to $100 \mathrm{mmHg}$ and the fluid exit of resectoscope was kept opened for permitting minimal resistance to flow. Trans-operatory intrauterine distension pressure was then determined by a dynamic fluid column (irrigation flow $>0$ ) with values below $100 \mathrm{mmHg}$. When this condition was not enough to guarantee a good operatory field and higher pressure was necessary, the cases were then excluded.

Both monopolar and bipolar probes were included in this study. As customary, we previously selected patients to use mono or bipolar diathermy probe after discussing the benefit-cost ratio for each surgery as well as considering the economic resources of each individual. No scientific interest influenced this step. When the monopolar probe was chosen, we used a mixture composed of Sorbitol/Manitol 2.7/0.54\% (178 mOsm $/ \mathrm{kg}$; Frezenius $\mathrm{Kabi}^{\circledR}$ or B. Braun ${ }^{\circledR}$ $1000 \mathrm{~mL}$ bags) as non-electrolytic distension fluid (without ionic solutes); this solution permits a perfect cut and coagulation, which was performed with a rigid continuous flow operative hysteroscope (Karl Storz ${ }^{\circledR}$ Endoskope - Germany). Monopolar hysteroscopic endometrial ablation, when indicated, was performed with a $5 \mathrm{~mm}$ loop wire diameter and rollerball device. When the bipolar probe was chosen, we used Normal Saline 0.9\% (308 mOsm/kg; Frezenius Kabi ${ }^{\circledR}$ or Halex lstar ${ }^{\circledR} 1000 \mathrm{~mL}$ bags) as the uterine distention media, and the Gynecare ${ }^{\circledR}$ Versapoint Electrosurgical System (Johnson \& Johnson Gateway -USA) bipolar resectoscope was used to perform the surgery; the loop and the bipolar shaver electrode were used to perform endometrectomy.

Regarding covariates assessment, patients were grouped according to Fallopian tube patency: those who previously had and had not been submitted to tubal ligation in the past. Also, the variable age was dichotomized in order to consider the ovarian status and its possible physiological influences on the uterus as a discrete variable; since menopause occurs, at an average age of 50.7 years $^{27}$ and can last several years ${ }^{28}$, the age 50 years was chosen to group women: age $>50 y e a r s$ (peri- and post-menopause period) and age 
$\leq 50 y e a r s$ (pre-menopause). All surgeries in which a fibroid resection was made were included in the myomectomy group, no matter what other procedures were also performed. Others were grouped in the without-myomectomy group. Large/ample adhesiolysis (3 cases) were also included in myomectomy group because it is also known to be a very risky procedure for overload ${ }^{8}$. Hysterometry $(\mathrm{cm})$ was determined immediately before surgery, when patients had just gone under anesthesia. Body surface area (SA) was calculated for each individual according the formula: SA $\left(\mathrm{m}^{2}\right)=$ [weight $(\mathrm{kg}) \times$ height $\left.(\mathrm{cm}) / 3,600\right]^{1 / 2}$. Total surgical time $(\mathrm{min})$ integrated the period between the beginning and the end of the uterus pressurization.

In a pilot approach, we assessed overfill of the solution bags for actual measurement of pumped fluid, as recommended in previous studies ${ }^{5,8}$. The actual volume $(\mathrm{mL})$ was previously verified in three samples of each commercial product with a $1,000 \mathrm{~mL}$ graduated glass cylinder (scale $=5 \mathrm{~mL}$ ), and the respective averages were used to calculate fluid balance at each surgery. With respect to overfill in Sorbitol/ Manitol 2.7/0.54\% bags, the actual volume of a 1,000 mL bag averaged $1,014 \mathrm{~mL}$ from Frezenius $\mathrm{Kabi}^{\circledR}(1,011$ to $1,016 \mathrm{~mL})$ and $1,022 \mathrm{~mL}$ from B Braun ${ }^{\circledR}$ bags $(1,016$ to $1,025 \mathrm{~mL}$ ). In Normal Saline $0.9 \%$, the actual volume of a $1,000 \mathrm{~mL}$ bag averaged $1,013 \mathrm{~mL}$ from Frezenius $\mathrm{Kabi}^{\circledR}$ $(1,000$ to $1,023 \mathrm{~mL})$ and $1,024 \mathrm{~mL}$ in Halex $1 \operatorname{lstar}^{\circledR}(1,012$ to $1,037 \mathrm{~mL})$. Commercial products were then identified and respective volumetric factors were used for correcting fluid balance in each surgery.

In all cases, the same trained nurse was responsible for the trans-operatory fluid balance under express supervision of the anesthesiologists (MFF and EAN). The volume of distension solution that was absorbed was checked after each 2,000 $\mathrm{mL}$ of pumped solution. After considering respective bag overfill for correcting total fluid balance, we calculated two different endpoints as dependent variables (targets): total intravasation and mean absorptionrate.

This study was previously approved by the Research Ethics Committee of Instituto Nacional de Saúde da Mulher, da Criança e do Adolescente Fernandes Figueira - Fundação Oswaldo Cruz (CEP IFF-FIOCRUZ Number 0045.0.008.000-07, Comissão Nacional de Ética em Pesquisa, Ministério da Saúde do Brasil) in accordance with the Guidelines and Regulatory Standards for Research Involving Human Beings.

\section{Statistics}

We used the Kolmogorov-Smirnov test to assay the null hypothesis of normality of distribution of continuous variables and Levene's test for Equality of Variances to consider homoscedasticity (ideal conditions for performing parametric statistic). Finally, we also verified on multiple regression that the residuals (predicted minus observed values) were distributed close to normal (i.e., they follow a Gaussian distribution). We used Student's $t$ test to compare means and parametric bivariate correlation (Pearson) to evaluated association among continuous variables. All significance tests that were two-tailed were considered statistically significant when $\mathrm{p}<0.05^{29,30}$.

We used different multiple linear regression models (MLRMs) to assess both total intravasation $(\mathrm{mL})$ and intravasation rate $\left(\mathrm{mL} \cdot \mathrm{min}^{-1}\right)$ as a dependent variable. In the proposed MLRMs, the value of each target variable could be simultaneously estimated from those called independent variables (regressors). Afterward, significances of the partial linear regression coefficients and intercept (constant) were statistically tested; the unstandardized coefficients (B) reflected the original units in which the variables were measured whereas standardized coefficients $(\beta)$ provided the estimate of the average number of standard deviations change in the criterion that could be produced by a change of one standard deviation in the regression concerned. Comparable small Beta values for some independent variables showed that they play minor parts in the regression ${ }^{29,31}$. The standard model (Enter) requested a standard regression analysis including all predictors that were tested. The optimized model (Backward Stepwise) excluded the non-significant coefficients one by one to keep only significant predictors and improve the coefficient of determination (adjusted $\mathrm{R}^{2}$ ). Type of energy (mono/bipolar probe), fallopian tube patency (with/without tubal ligation), hysterometry $(\mathrm{cm})$, age (older/ younger than 50 years old), body surface area $\left(\mathrm{m}^{2}\right)$, surgery (with/without myomectomy) and surgical time (min) were tested as independent variables (predictors) possibly capable to predict total intravasation. Furthermore, we tested the same variables (except surgical time) as predictors of intravasation rate. Despite being a major factor contributing to fluid intravasation, intrauterine fluid pressure was not an independent variable in the analysis because it was considered constant. Statistical analyses were run with SPSS 15.0 for Windows (www.spss.com - USA) ${ }^{31}$.

\section{Results}

Patients' ages varied from 22 to 86 years old (mean $=49.1$; standard deviation $(\mathrm{SD})=12$ ), and the characteristics of the sample were summarized in Table 1.

First of all, our results confirmed that overfilled bags could affect the accuracy if fluid balance were calculated without overfill correction, especially in procedures that took more time, in which more irrigating fluid was pumped. The difference (uncorrected minus corrected deficit) should be called "unrecognized intravasation". In this series, the maximal underestimation of absorbed fluid would have occurred after a (bipolar) multiple myomectomy using normal saline (surgical time: $75 \mathrm{~min}$; total pumped fluid: 14,800 $\mathrm{mL}$; corrected total intravasation: $2,851 \mathrm{~mL}$; average overfill: 
$4.4 \%)$. In this case, without overfill correction, total intravasation would have been calculated as only 2,200 $\mathrm{mL}$ and the error would have been $651 \mathrm{~mL}$, which is a relevant value.

As expected, mean total intravasation was significantly higher when myomectomy was performed ( $442 \pm 616$ versus $223 \pm 332 \mathrm{~mL} ; \mathrm{p}<0.01)$. However, despite mean intravasation rate has also been higher during myomectomy, the difference was not significant $(21 \pm 25$ versus $15 \pm 19 \mathrm{~mL} / \mathrm{min} ; \mathrm{p}=0.09)$. Women with previous tubal ligation averaged comparable values for total intravasation $(190 \pm 315$ versus $233 \pm 332 \mathrm{~mL}$; $\mathrm{p}=0.4)$ and intravasation rate $(13 \pm 15$ versus $14 \pm 19 \mathrm{~mL} / \mathrm{min}$; $\mathrm{p}=0.5$ ) when compared to women with no tubal ligation. Total fluid absorption was significantly lower when surgeries were performed with monopolar probe $(228 \pm 240$ versus $401 \pm 568 \mathrm{~mL} ; \mathrm{p}=0.01$ ), but difference between intravasation rate means was not statistically significant $(15 \pm 19$ versus $20 \pm 25 \mathrm{~mL} / \mathrm{min} ; \mathrm{p}=0.1)$. Comparing cases in which the functional ovarian status was considered poor (age $>50$ years old) with cases in which ovarian function was considered preserved (age $\leq 50$ years old), differences were not significant for intravasation $(197 \pm 285$ versus $293 \pm 421 \mathrm{~mL} ; \mathrm{p}=0.08)$ and intravasation rate $(16 \pm 19$ versus $15 \pm 21 \mathrm{~mL} ; \mathrm{p}=0.5)$. Considering the 15 surgeries in which total intravasation was $>1,000 \mathrm{~mL}$, only in 5 included myomectomy, although the mean total intravasation had been significantly higher when fibroid resection occurred. This issue suggests a noteworthy influence of some other concomitant variables and justified a multivariate statistical approach. These comparisons are summarized in Table 2.

According to parametric bivariate analysis (Pearson), total intravasation showed significant correlation with body surface area $(r=0.5 ; \mathrm{p}<0.01)$, hysterometry $(\mathrm{r}=0.5$; $\mathrm{p}<0.01)$ and duration $(\mathrm{r}=0.65 ; \mathrm{p}<0.01)$. Also, intravasation rate showed significant correlation with body surface area $(\mathrm{r}=0.61 ; \mathrm{p}<0.01)$ and hysterometry $(\mathrm{r}=0.61 ; \mathrm{p}<0.01)$.

Considering the Backward Stepwise our best proposed multivariate model for total intravasation (model 2: adjusted $\left.\mathrm{R}^{2}=0.44 ; \mathrm{p}<0.01\right)$, the partial linear regression coefficients for the variables myomectomy $(\mathrm{B}=176.9 ; \mathrm{p}<0.01)$ and duration $(\mathrm{B}=10.8 ; \mathrm{p}<0.01)$ were the most important, as expected. Concerning the best proposed multivariate model for intravasation rate (model $4: \mathrm{R}^{2}=0.39 ; \mathrm{p}<0.01$ ), the main partial linear regression coefficients were found for the variables

Table 1. Characteristics of the sample $(\mathrm{n}=200)$

\begin{tabular}{l|c|c|c|c}
\hline & Mean & $95 \% \mathrm{Cl}$ & Minimum & Maximum \\
\hline Age (years) & 49.1 & $47.4-50.9$ & 22 & 86 \\
Weight $(\mathrm{kg})$ & 67.3 & $65.0-69.6$ & 45 & 150 \\
Height $(\mathrm{cm})$ & 159.3 & $158.1-160.4$ & 143 & 186 \\
BSA $\left(\mathrm{m}^{2}\right)$ & 1.7 & $1.69-1.75$ & 1.4 & 2.7 \\
Hysterometry $(\mathrm{cm})$ & 8.1 & $7.9-8.3$ & 5 & 12 \\
\hline
\end{tabular}

BSA: Body surface area $=[\text { weight }(\mathrm{kg}) \times \text { height }(\mathrm{cm}) / 3,600]^{\frac{1}{2}} ; 95 \% \mathrm{Cl}: 95 \%$ confidence interval. myomectomy $(\mathrm{B}=11.0 ; \mathrm{p}=0.02)$ and hysterometry $(\mathrm{B}=1.5$; $\mathrm{p}<0.01)$. Indeed, it is important to make clear that the variable intravasation rate, obviously, encompasses the variable surgical time (duration), which was the main significant predictor of total intravasation, besides myomectomy (Table 3).

Table 2. Total intravasation and intravasation rate in 200 consecutive operative hysteroscopies

\begin{tabular}{|c|c|c|c|c|c|c|c|}
\hline & & \multicolumn{3}{|c|}{ Total intravasation (mL) } & \multicolumn{3}{|c|}{ Intravasation rafe (mL/min) } \\
\hline & $\begin{array}{c}\text { Frequency } \\
\text { n (\%) }\end{array}$ & Mean & $95 \% \mathrm{Cl}$ & p-value & Mean & $95 \% \mathrm{Cl}$ & p-value \\
\hline $\begin{array}{l}\text { Without } \\
\text { myomectomy }\end{array}$ & $158(79)$ & 223 & $-362-75$ & $<0,01$ & 15 & -13-1 - & 0.09 \\
\hline $\begin{array}{l}\text { With } \\
\text { myomectomy }\end{array}$ & $42(21)$ & 442 & & & 21 & & \\
\hline $\begin{array}{l}\text { No tubal } \\
\text { ligation }\end{array}$ & $128(64)$ & 233 & $-61-148$ & 0.42 & 14 & $-4-7$ & 0.57 \\
\hline $\begin{array}{l}\text { Previous } \\
\text { tubal } \\
\text { ligation }\end{array}$ & $72(36)$ & 190 & & & 13 & & \\
\hline $\begin{array}{l}\text { Monopolar } \\
\text { probe }\end{array}$ & $152(76)$ & 228 & $-305-42$ & 0.01 & 14 & $-11-2$ & 0.15 \\
\hline $\begin{array}{l}\text { Bipolar } \\
\text { probe }\end{array}$ & $48(24)$ & 401 & & & 20 & & \\
\hline $\begin{array}{l}\leq 50 \text { years } \\
\text { old }\end{array}$ & $116(58)$ & 293 & -10-203 & 0.08 & 16 & $-4-7$ & 0.57 \\
\hline $\begin{array}{l}>50 \text { years } \\
\text { old }\end{array}$ & $84(42)$ & 197 & & & 15 & & \\
\hline
\end{tabular}

Comparison between means according to dichotomized variables (ktest); $p$ : significance (two-tailed); $95 \% \mathrm{Cl}$ : $95 \%$ confidence interval of the difference between means.

Table 3. Multiple linear regression models through the origin (no intercept) and bivariate correlation analysis for total intravasation ( $\mathrm{mL}$; models 1 and 2) and intravasation rate $(\mathrm{mL} / \mathrm{min}$; models 3 and 4$)$ as dependent variables $(\mathrm{n}=200)$

\begin{tabular}{|c|c|c|c|c|c|}
\hline Predictors & $\mathrm{B}$ & $95 \% \mathrm{Cl}$ for $\mathrm{B}$ & $\beta$ & $\mathrm{p}$-value & r (Pearson) \\
\hline \multicolumn{6}{|c|}{ Model 1 (adjusted $R^{2}=0.43 ; p<0.01$ ) } \\
\hline Age $\geq 50$ years & 9.9 & $-91-111$ & 0.02 & 0.85 & \\
\hline Tubal ligation & -32.5 & $-137-72$ & -0.05 & 0.54 & \\
\hline Bipolar energy & 72.4 & $-59-204$ & 0.08 & 0.28 & \\
\hline Myomectomy & 140.4 & $2-279$ & 0.15 & 0.05 & \\
\hline Surface area $\left(m^{2}\right)$ & -13.1 & $-185-159$ & -0.06 & 0.88 & $0.58[p<0.01]$ \\
\hline Hysterometry (cm) & 10.0 & $-27-47$ & 0.23 & 0.54 & $0.59[p<0.01]$ \\
\hline Duration (min) & 8.2 & $4-12$ & 0.44 & $<0.01$ & $0.65[p<0.01]$ \\
\hline \multicolumn{6}{|c|}{ Model 2 (adjusted $R^{2}=0.44 ; p<0.01$ ) } \\
\hline Myomectomy & 176.9 & $48-306$ & 0.19 & $<0.01$ & \\
\hline Duration (min) & 10.8 & $8-13$ & 0.58 & $<0.01$ & \\
\hline \multicolumn{6}{|c|}{ Model 3 (adjusted $\mathbf{R}^{2}=0.38 ; p<0.01$ ) } \\
\hline Age $\geq 50$ years & 1.8 & $-5-9$ & 0.05 & 0.60 & \\
\hline Tubal ligation & -1.8 & $-9-15$ & -0.05 & 0.60 & \\
\hline Bipolar energy & 1.4 & $.7-10$ & 0.03 & 0.75 & \\
\hline Myomectomy & 10.8 & $2-20$ & 0.18 & 0.02 & \\
\hline Surface area $\left(m^{2}\right)$ & 2.6 & $-9-14$ & 0.19 & 0.44 & $0.61[p<0.01]$ \\
\hline Hysterometry (cm) & 0.9 & $-1.4-3.3$ & 0.33 & 0.43 & $0.61[p<0.01]$ \\
\hline \multicolumn{6}{|c|}{ Model 4 (adjusted $\mathrm{R}^{2}=0.39 ; \mathrm{p}<0.01$ ) } \\
\hline Myomectomy & 11.0 & $2-20$ & 0.18 & 0.02 & \\
\hline Hysterometry (cm) & 1.5 & $1.1-1.9$ & 0.54 & $<0.01$ & \\
\hline
\end{tabular}

Models 1 and 3 (Enter) request a standard regression analysis; Models 2 and 4 (Backward Stepwise) exclude non-significant coefficients (one by one) and repeats the analysis for keeping only the significants; $B$ : unstandardized coefficients; $\beta$ : standardized coefficients; $95 \% \mathrm{Cl}$ : $95 \%$ confidence interval; $\mathrm{R}^{2}$ : coefficient of determination for multivariate model; r: coefficient of correlation between two continuous variables. 


\section{Discussion}

In this preplanned prospective observational study with 200 cases, we verified that a measurement of the size of the uterus (obtained using a hysterometer) also should be taken into account in operative hysteroscopy as an additional independent variable capable to, preoperatively, alert the team for the risk of fluid overload. Furthermore, the surgical lenght was confirmed to be the main predictor of total intravasation, particularly when a myomectomy (also a significant predictor) is performed.

Before multivariate analysis, the simple statistical comparison between two means ( $t$-test) erroneously pointed a significant influence of bipolar probe on total intravasation. This was probably due to confounding factors because there was no significant coefficient for bipolar probe use when the cases were considered in a MRLM. Therefore, our results corroborate the hypothesis of higher permissibility of surgical time when electrolytic solution is used; surgeries with longer durations have been the main foundation for higher total intravasation with a bipolar probe. Our team thinks electrolytic fluids are the safest distension media, especially for more complex hysteroscopic resections (i.e. multiple myomatosis or large/ample adhesiolysis). However, this safety should not be overestimated because cardiovascular disturbances that indicate gaseous embolism during transcervical resection of myomas may occur despite the limitation of intravasation ${ }^{32}$ even if bipolar diathermia is used ${ }^{25}$.

There are uncommon uterine conditions, which can predispose patients to massive absorption and fluid overload. Taking into account the ESGE (European Society for Gynaecological Endoscopy) and STEPW (Size, Topography, Extension, Penetration, and Wall) classifications to submucous myomas, the STEPW classification allows better prediction of myoma removal, fluid balance, length of surgery and surgical complications in hysteroscopic myomectomy than ESGE classification ${ }^{33}$. Moreover, the location of the myomas does not matter when patient hasa uterus with multiple myomas and low compliance for fluid distention and high vascularization. These conditions may be linked to a higher chance of transforming hysteroscopic surgery into a more complex and risky procedure $^{2,14,32}$, even when using a bipolar probe is used.

Our team has performed (and we do recommend) repeated fluid balance and a frequent evaluation about the possibility of stopping surgery when/if a tendency toward high absorption is detected ${ }^{14}$. Also, according to Deffieux et al..$^{34}$, if the fluid deficit of $2,000 \mathrm{~mL}$ of irrigation is reached, surgery must be stopped. Actually, if the absorbed fluid volume is continually monitored, time control becomes less important ${ }^{14}$. Although patients are different and there is no rule for defining a maximal fluid input, pressure must be as minimal as possible in all cases, especially if the fluid lacks sodium. In addition, it is important to pay attention to usual temperature of distension fluid during $\mathrm{OH}$ because a cool fluid is more viscous than a warm one ${ }^{35}$. Thus, it is possible that the choice of warm distension solutions increases the risk and does not allow longer surgical times ${ }^{26}$.

Some strength points in this study include the extent to which the results can be generalized to other situations and to other people (external validity). We can infer that our conclusions can be actually applied in other geographic locations, since the sample showed a wide heterogeneity. Moreover, considering the study design, observational studies may be better able to reflect outcomes obtained in everyday practice ${ }^{36}$.

Despite all our efforts to prevent and mitigate both measurement bias and confounding, we recognize that some characteristics of design and methodology may have influenced the application or interpretation of the results of our study. These limitations include inaccuracies when assessing hysterometry, measuring peri-operative fluid volumes and when using a dichotomized surrogate variable (age $>50 y$ ) in place of the actual ovarian status. Last, but not least, the possibility of influence of some unknown variable cannot be rejected since the absorption occurs mainly into the vessels opened during the procedure ${ }^{37}$.

Considering the intrauterine pressure and duration constant, we verified that myomectomy procedure and hysterometry were significant predictors for intravasation rate during operative hysteroscopy whereas bipolar energy (compared to monopolar), fallopian tube patency, age $\leq 50$ years and body surface area were not. Besides, we conclude that intra-operative intermittent monitoring of intravasation amount should be mandatory not only during longer myomectomies or large uterus, since high irrigating fluid absorption might also occur during less complex procedures.

\section{Acknowledgements}

National Council of Scientific and Technological Development of Brazil (CNPq). The authors acknowledge the invaluable assistance of the nurses Ana P. Miranda and Roberta P. da Luz Fonseca. 
1. Julian TM. Hysteroscopic complications. J Low Genit Tract Dis. 2002;6(1):39-47.

2. Di Spiezio Sardo A, Mazzon I, Bramante S, Bettocchi S, Bifulco G, Guida $M$, et al. Hysteroscopic myomectomy: a comprehensive review of surgical techniques. Hum Reprod Update. 2008;14(2):101-19.

3. Indman PD, Brooks PG, Cooper JM, Loffer FD, Valle RF, Vancaillie TG. Complications of fluid overload from resectoscopic surgery. J Am Assoc Gynecol Laparosc. 1998;5(1):63-7.

4. Rassweiler J, Teber D, Kuntz R, Hofmann R. Complications of Transurethral Resection of the Prostate (TURP): incidence, management, and prevention. Eur Urol. 2006;50(5):969-79.

5. Sutton C. Hysteroscopic surgery. Best Pract Res Clin Obstet Gynaecol. 2006;20(1):105-37.

6. AAGL Advancing Minimally Invasive Gynecology Worldwide. AAGL Practice Report: practice guidelines for the management of hysteroscopic distending media: (Replaces hysteroscopicm fluid monitoring guidelines. J Am Assoc Gynecol Laparosc. 2000;7:167. 8). J Minim Invasive Gynecol. 2013;20(2):137-48.

7. Camanni M, Bonino L, Delpiano EM, Ferrero B, Migliaretti G, Deltetto F. Hysteroscopic management of large symptomatic submucous uterine myomas. J Minim Invasive Gynecol. 2010;17(1):59-65.

8. Nezhat $\mathrm{CH}$, Fisher DT, Datta S. Investigation of often-reported ten percent hysteroscopy fluid overfill: is this accurate? J Minim Invasive Gynecol. 2007;14(4):489-93.

9. Kim AH, Keltz MD, Arici A, Rosenberg M, Olive DL. Dilutional hyponatremia during hysteroscopic myomectomy with sorbitolmannitol distention medium. J Am Assoc Gynecol Laparosc. $1995 ; 2(2): 237-42$.

10. Mushambi MC, Williamson K. Anaesthetic considerations for hysteroscopy surgery. Best Pract Res Clin Anaesthesiol. 2002; 16(1):35-52.

11. Schäfer M, Von Ungern-Sternberg BS, Wight E, Schneider MC. Isotonic fluid absorption during hysteroscopy resulting in severe hyperchloremic acidosis. Anesthesiology. 2005;103(1):203-4.

12. Brandstrup $B$. Fluid therapy for the surgical patient. Best Pract Res Clin Anaesthesiol. 2006;20(2):265-83.

13. Fonseca MF, Nogueira EA, Gemal AE, Andrade JLG. Anestesia em videocirurgia: fundamentos para o cirurgião. In: Crispi CP (editor). Tratado de videoendoscopia ginecológica. 2a ed. São Paulo: Atheneu; 2006. p. 75-89.

14. Fonseca MF, Andrade Junior CM, Nogueira EA, Santos LCS, Crispi CP. Is time monitoring really necessary for preventing fluid overload in hysteroscopic surgery? A case report. Braz J VideoSur. 2008; 1 (3):128-32.

15. Adrogué HJ, Madias NE. Hyponatremia. N Engl J Med. 2000;342(21):1581-9.

16. Fukagawa $M$, Kurokawa K, Papadakis MA. Fluid \& electrolyte disorders. In: Tierney LM Jr, McPhee SJ, Papadakis MA(editors). Current medical diagnosis \& treatment. 45th ed. New York: McGraw-Hill; 2006. p. 865-95.

17. Ananthanarayan C, Paek W, Rolbin SH, Dhanidina K. Hysteroscopy and anaesthesia. Can J Anaesth. 1996;43(1):56-64.

18. Yaprak M, Turan MN, Tamer AF, Peker N, Demirci MS, Çırpan $T$, et al. How quickly can acute symptomatic hyponatremia be corrected? Int Urol Nephrol. 2013;45(6):1805-8.
19. Singh H, Desai MR, Shrivastav P, Vani K. Bipolar versus monopolar transurethral resection of prostate: randomized controlled study. J Endourol. 2005; 19(3):333-8.

20. Ho HS, Cheng CW. Bipolar transurethral resection of prostate: a new reference standard. Curr Opin Urol. 2008;18(1):50-5.

21. Ramsay JW, Shepherd NA, Butler M, Gosling PT, Miller RA, Wallace DM, et al. A comparison of bipolar and monopolar diathermy probes in experimental animals. Urol Res. 1985;13(2):99-102.

22. Varol N, Maher P, Vancaillie T, Cooper M, Carter J, Kwok A, et al. $A$ literature review and update on the prevention and management of fluid overload in endometrial resection and hysteroscopic surgery. Gynaecol Endosc. 2002;11(1):19-26.

23. Tuchschmid S, Bajka M, Szczerba D, Lloyd BA, Székely G, Harders M. Modelling intravasation of liquid distension media in surgical simulators. Med Image Comput Comput Assist Interv. 2007; 10(Pt 1):717-24.

24. Molnar BG, Broadbent JA, Magos AL. Fluid overload risk score for endometrial resection. Gynaecol Endosc. 1992;1(3):133-8.

25. Dyrbye BA, Overdijk LE, van Kesteren PJ, de Haan P, Riezebos RK, Bakkum EA, et al. Gas embolism during hysteroscopic surgery using bipolar or monopolar diathermia: a randomized controlled trial. Am J Obstet Gynecol. 2012;207(4):271.e 1-6.

26. De Freitas Fonseca M, Andrade CM Jr, de Mello M, Crispi CP. Effect of temperature on fluidity of irrigation fluids. $\mathrm{Br} J$ Anaesth. $2011 ; 106(1): 51-6$.

27. McKinlay SM, Brambilla DJ, Posner JG. The normal menopause transition. Maturitas. 1992;14(2):103-15.

28. Nelson HD. Menopause. Lancet. 2008;371(9614):760-70.

29. Cochran WG, Cox GM. Experimental designs. Chichester: John Wiley \& Sons; 1950.

30. Pocock SJ. Clinical trials: a practical approach. Chichester: John Wiley \& Sons; 1983.

31. Kinnear PR, Gray CD. SPSS 15 made simple. Hove: Psychology Press; 2008.

32. Rademaker BM, van Kesteren PJ, de Haan P, Rademaker D, France C. How safe is the intravasation limit in hysteroscopic surgery? J Minim Invasive Gynecol. $2011 ; 18(3): 355-61$.

33. Lasmar RB, Lasmar BP, Celeste RK, da Rosa DB, Depes DB, Lopes RG. A new system to classify submucous myomas: a Brazilian multicenter study. J Minim Invasive Gynecol. 2012;19(5):575-80.

34. Deffieux X, Gauthier T, Menager N, Legendre G, Agostini A, Pierre F. Hysteroscopy: guidelines for clinical practice from the French College of Gynaecologists and Obstetricians. Eur J Obstet Gynecol Reprod Biol. 2014;178:114-22.

35. Faria MAF, Sá CF, Lima GR, Filho JIBC, Martins RJ, Cardoso MEM, et al. Measurement of density and viscosity of binary 1-alkanol systems $\left(\mathrm{C}_{8}-\mathrm{C}_{11}\right)$ at $101 \mathrm{KPa}$ and temperatures from (283.15 to 313.15) K. J Chem Eng Data. 2005;50(6):1938-43.

36. Papanikolaou PN, Christidi GD, loannidis JP. Comparison of evidence on harms of medical interventions in randomized and nonrandomized studies. CMAJ. 2006;174(5):635-41.

37. Istre $O$. Fluid balance during hysteroscopic surgery. Curr Opin Obstet Gynecol. 1997;9(4):219-25. 